\title{
Assessment of Self-Purification Process of Thi Nai lagoon (Binh Dinh Province, Viet Nam)
}

\author{
Trang Cao Thi Thu ${ }^{1}$, Dieu Luu Van ${ }^{1}$, Thanh Tran $\operatorname{Duc}^{1} \& \operatorname{Sinh}$ Le Xuan ${ }^{1}$ \\ ${ }^{1}$ Institute of Marine Environment and Resources, No. 246, Da Nang Street, HaiPhong City, VietNam \\ Correspondence: Sinh Le Xuan, Institute of Marine Environment and Resources, No. 246, Da Nang Street, \\ HaiPhong City, VietNam. Tel: 84-972-346-858. E-mail: sinhlx@gmail.com
}

Received: April 20, 2015 Accepted: April 30, 2015 Online Published: July 1, 2015

doi:10.5539/enrr.v5n3p19 URL: http://dx.doi.org/10.5539/enrr.v5n3p19

\begin{abstract}
Processes related to self-purification of Thi Nai lagoon has been studied in-situ and in laboratory in rainy season (October, 2013) and in dry season (May, 2014). Studied results shows that the capacity of self-purification of Thi Nai lagoon is quite good in rainy season, and the dominated process is material exchange. In dry season, due to the weak of material exchange, there is the accumulation of pollutants in water body, especial for nitrite, ammonium and phosphate. The studied results also indicate that the main processes that dominate the self-purification of Thi Nai lagoon are materials exchange, sedimentation, dispersion, decompose, and photosynthesis, respectively. The pollution loads discharged everyday into the Thi Nai lagoon is high, reducing the self-purification of lagoon, therefore it need to be controlled restrict.
\end{abstract}

Keywords: self-purification, process, mass balance, lagoon

\section{Introduction}

Thi Nai lagoon area located in the coordinate of $109^{\circ} 10^{\prime} 00^{\prime \prime}-109^{\circ} 17^{\prime} 00^{\prime \prime} \mathrm{E} ; 3^{\circ} 45^{\prime} 00^{\prime \prime}-13^{\circ} 56^{\prime} 30^{\prime \prime} \mathrm{N}$, belong to Binh Dinh province, Viet Nam. It is surrounded by Phuoc Thang, Phuoc Hoa, Phuoc Son, Phuoc Thuan communes (Tuy Phuoc district), Nhon Hoi, Nhon Binh, Hai Cang and Dong Da wards (Quy Nhon city). Thi Nai lagoon has length of $15.5 \mathrm{~km}$, width of $500 \mathrm{~m}-5,000 \mathrm{~m}$. It connects to Tuy Phuoc and Phu Cat communes in the North, to Quy Nhon city in the South, to Tuy Phuoc commune and Quy Nhon city in the West and to coastal sand-bank in the East. On administration, the lagoon is managed by Quy Nhon city, Tuy Phuoc and Phu Cat districts. Thi Nai lagoon has area of 5,060 ha at high tide and of 3,200 ha at low tide. The mouth of lagoon connects to Quy Nhon bay with the width of 500-700 m. The tidal flat area is in range of 1,800 ha $-2,000 \mathrm{ha}$.

It is well-know fact that the waste/ pollutants discharged into the natural water bodies such as rivers, lakes and the sea disappear slowly with time. The removal of pollutants from a water body without any artificial controls is called self-purification, or natural purification (Koichi \& Hong, 2002). The mechanism of self-purification of water bodies can be divided into three groups: physical processes, chemical processes and biological processes. Physical processes contributing to the removal of pollutants from a natural water body include dilution $/ \mathrm{mixing}$ by inflow by unpolluted water into the water body, diffusion of pollutants in water body, and precipitation/filtration of the pollutants to the sediment (Ifabiyi, 2008; Hanelore, 2013). The volatilization of volatile pollutants from water to the atmosphere will also result in a decrease of pollutants in the water (Keqiang, Ying, Jun, Xiulin, \& Jinbo, 2012). Chemical processes related to the removal of pollutants from a water body are oxidation by oxidants such as ultraviolet, ozone and oxygen, reduction by reductants and neutralization. The biological processes include degradation/transformation of organic pollutants by bacteria by aerobic or an aerobic conditions, and nitrification and denitrification of ammonia and nitrate, respectively (Beyers \& Odum, 1993; Drinan \& Spellman, 2001; Grice \& Reeve, 1982; Hily, 1991; Loo \& Rosenberg, 1989; Logan \& Hunt, 1987; Mandi, Houhoum, Asmama, \& Schwartzbrod, 1996; Stimson, Larned, \& McDermid, 1996). Biological processes play the most important role among the mechanisms of self - purification in natural water bodies (Koichi \& Hong, 2002). Several natural biological filters also contribute in natural purification (Hily, 1991; Loo et al., 1989; Logan et al., 1987; Mandi et al., 1996; Stimson et al., 1996). The biological removal of pollutants from a natural water body is usually called "true self-purification" and the total purification by physical, chemical and biological processes is called "apparent self-purification" (Koichi \& Hong, 2002). 
In Viet Nam, self-purification of a water body is not studied yet. In 1999, pollution mechanism of Ha Long Bay had been studied by Japan International Cooperation Agency experts JICA (1999). In this study, some experiments of the sedimentation and dispersion of pollutant and the photosynthesis of phytoplankton in water and the decomposition of organic pollutants in Ha Long Bays had been carried out. From that, accumulation of pollutants in water body was assessed. It is a good method to assess the self-purification of a water body. Based on that study, we apply this method to Thi Nai lagoon to assess the self-purification of it.

This paper presents the study on self-purification of Thi Nai lagoon, contributing in understanding of processes in lagoon, from that finding which process dominates the self-purification of Thi Nai lagoon.

\section{Materials and Methodology}

\subsection{Study Area}

Study area is Thi Nai lagoon, Binh Dinh province, Viet Nam. Location of Thi Nai lagoon was and experiment sites were given in figure 1. Two experiment sites in the lagoon were established to do experiments. Site TN-LT1 is located near the mouth of the lagoon and site TN-LT2 is arranged in the end of the lagoon. The average experiment data of two sites will be taken for further calculation. Experiments were done in rainy season (October, 2013) and dry season (May, 2014). Each period of experiment last 20 days includes 3 days in the field and remain days in the laboratory. The experiment of rainy season last from 14 October to 4 November, 2013 and the one of dry season last from 22 May to 10 July, 2014.

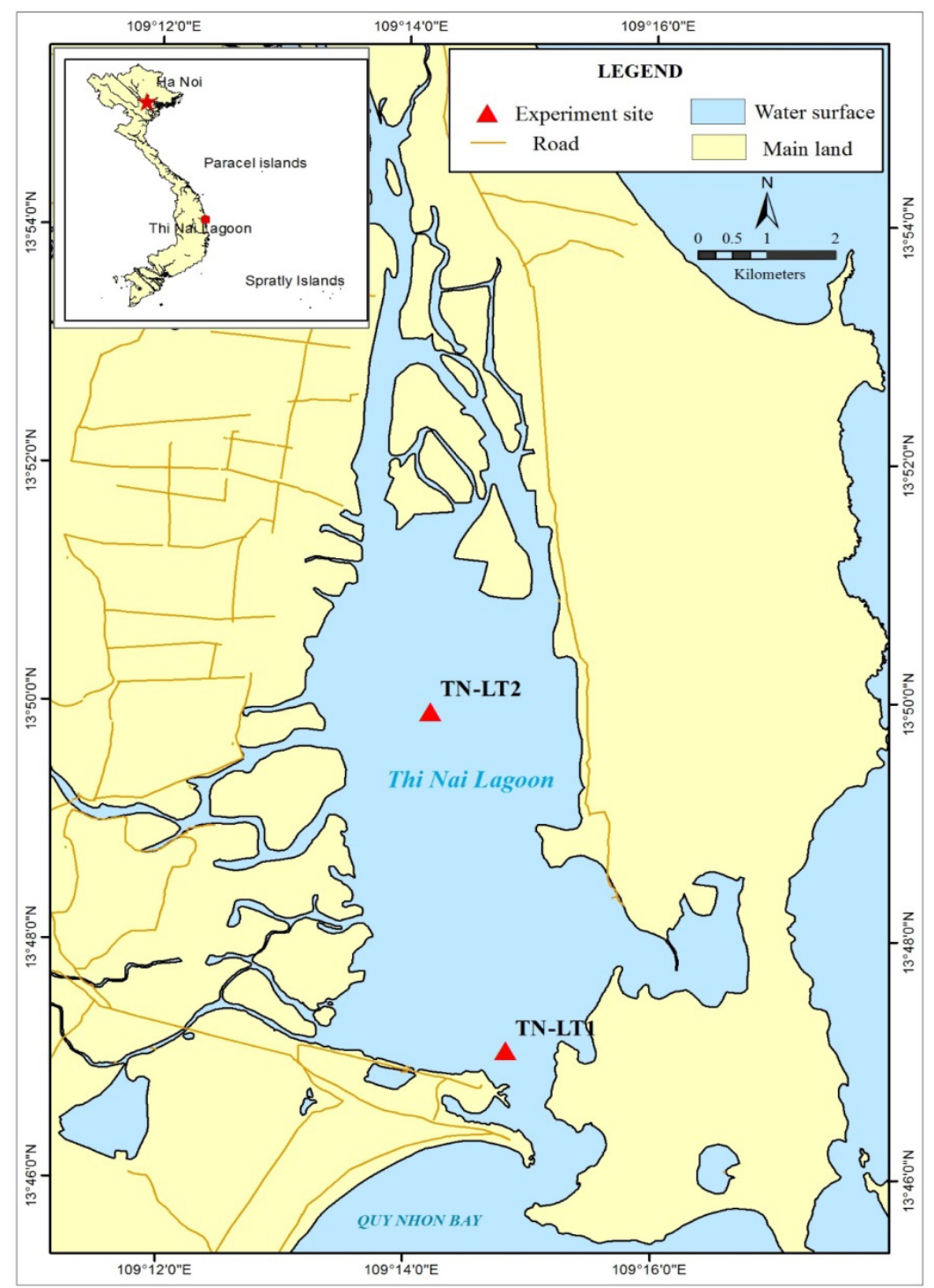

Figure 1. Experiment Sites of Thi Nai lagoon 


\subsection{Methods}

On principle, to assess the self-purification of Thi Nai lagoon, mass balance equation in a water body has been used as the following:

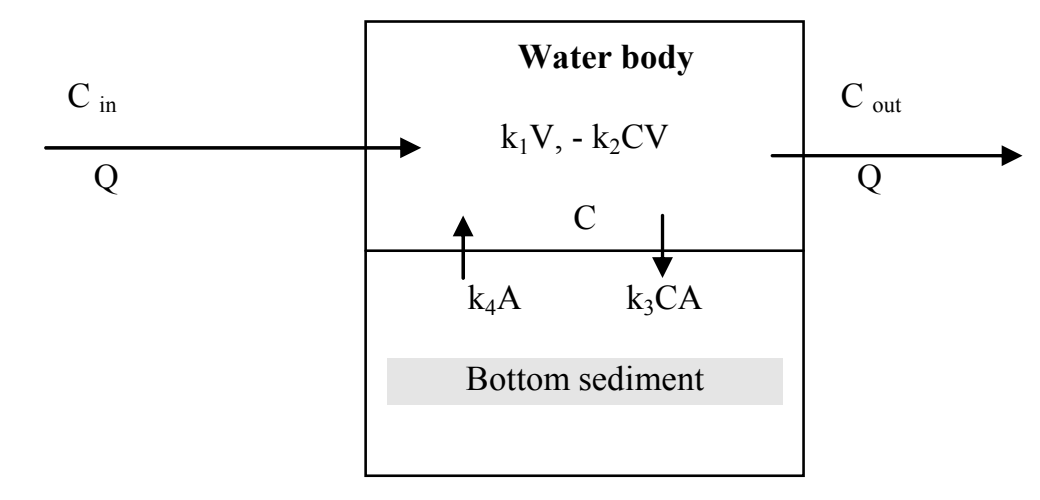

$$
\mathrm{L}=\mathrm{QC}_{\text {in }}-\mathrm{QC}_{\text {out }}+\mathrm{K}_{1} \mathrm{~V}-\mathrm{K}_{2} \mathrm{CV}-\mathrm{K}_{3} \mathrm{CA}+\mathrm{K}_{4} \mathrm{~A}
$$

(After JICA, 1999)

In which:

L: Total pollutants remain in lagoon $(\mathrm{kg} / \mathrm{day})$

C: Concentration of organic pollutants and nutrients in lagoon $\left(\mathrm{kg} / \mathrm{m}^{3}\right)$

$\mathrm{V}$ : Water volume in lagoon $\left(\mathrm{m}^{3}\right)$

$C_{\text {in }}$ : Concentration of organic pollutants and nutrients in flow in $\left(\mathrm{kg} / \mathrm{m}^{3}\right)$

$C_{\text {out }}$ : Concentration of organic pollutants and nutrients in flow out $\left(\mathrm{kg} / \mathrm{m}^{3}\right)$

A: Area of bottom sediment in lagoon $\left(\mathrm{m}^{2}\right)$

Q: Current flow ( $\mathrm{m}^{3} /$ day)

$\mathrm{K}_{1}$ : Primary productivity rate $\left(\mathrm{kg} / \mathrm{m}^{3} /\right.$ day $)$

$\mathrm{K}_{2}$ : Decompose rate (1/day)

$\mathrm{K}_{3}$ : Sedimentation rate ( $\mathrm{m} /$ day)

$\mathrm{K}_{4}$ : Dispersion rate $\left(\mathrm{kg} / \mathrm{m}^{2} /\right.$ day $)$

If $\quad \mathrm{L}<0$ : Good purification

$\mathrm{L}>0$ : Poor purification

2.3 Experiment Methods to Determine Coefficients of Mass Balance Equation (Figure 2):

\subsubsection{Describe Experiments and Data Treatment}

Sedimentation: An experiment system includes 4 pipes (length $0.5 \mathrm{~m}$, diameter $10 \mathrm{~cm}$ ) put into the sea bottom. Using heavy objects and buoys to keep system vertically and distance $0.5 \mathrm{~m}$ compare to bottom. Pollutants from surface water will fall down into pipes. After 72 hours, collect the system, mixing 4 pipes and collect water samples to measure parameters as $\mathrm{NO}_{2}^{-}, \mathrm{NO}_{3}{ }^{-}, \mathrm{NH}_{4}{ }^{+}, \mathrm{N}-\mathrm{T}, \mathrm{P}-\mathrm{T}, \mathrm{PO}_{4}{ }^{3-}, \mathrm{COD}, \mathrm{BOD} 5$, TSS. And then, calculate amount of pollutants settled in an area unit in the experiment time; convert to $\mathrm{g} / \mathrm{m}^{2} /$ day.

Photosynthesis: Surface and bottom water were poured into black and white containers and put into lagoon in the early morning (before sunrise) and collect in the late afternoon. Collect samples before and after experiment to analysis parameters as $\mathrm{pH}, \mathrm{DO}, \mathrm{NO}_{2}^{-}, \mathrm{NO}_{3}{ }^{-}, \mathrm{NH}_{4}{ }^{+}, \mathrm{PO}_{4}{ }^{3-}$. Calculate amount of organic substance produced in one day in each season and also calculate amount of mineral nutrients consumed during photosynthesis process.

Dispersion: Surface sediment and seawater were collected and put into glass tanks (volume 30 litter), in which the bottom area of tank as: $0.4 \mathrm{~m} \times 0.25 \mathrm{~m}=0.1 \mathrm{~m}^{2}$ and the thick of sediment layer was of $3-5 \mathrm{~cm}$, the height of water column was $0.3 \mathrm{~m}$. Glass tank was supplied oxygen continuously. After $0,2,5,10,15$ and 20 days, collect water samples and analysis parameters as temperature, $\mathrm{pH}, \mathrm{DO}, \mathrm{NO}_{2}^{-}, \mathrm{NO}_{3}^{-}, \mathrm{NH}_{4}^{+}, \mathrm{N}-\mathrm{T}, \mathrm{P}-\mathrm{T}, \mathrm{PO}_{4}{ }_{4}^{--}, \mathrm{COD}, \mathrm{BOD}_{5}$ to determine the dispersion pollutants from sediment into water. Calculate amount of pollutants dispersed from sediment into water in each $\mathrm{m}^{2}$ of sediment for each experiment site. 
Decomposition: Surface water and bottom water were collected into dark containers. After 0, 2, 5, 10, 15 and 20 days, pour water from these containers and analysis parameters as: temperature, $\mathrm{pH}, \mathrm{DO}, \mathrm{NO}_{2}^{-}, \mathrm{NO}_{3}^{-}, \mathrm{NH}_{4}^{+}$, $\mathrm{PO}_{4}{ }^{3-}, \mathrm{BOD}_{5}, \mathrm{COD}$ to determine the decomposition of organic pollutants.

Current flow and water quality were measured in 72 hours continuously in situ in 2 seasons to determine the exchange of substances in and out the lagoon. Delft 3D model was used to simulate water exchange and some hydraulic regime of lagoon.

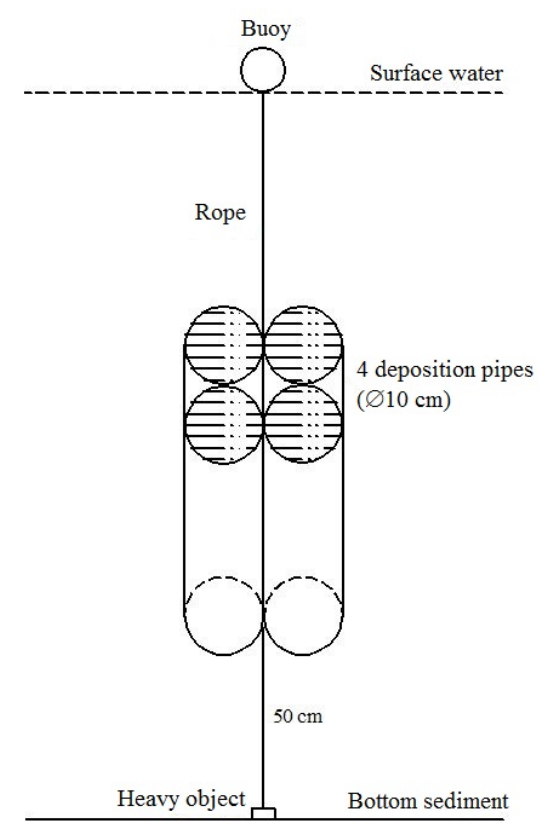

(a)

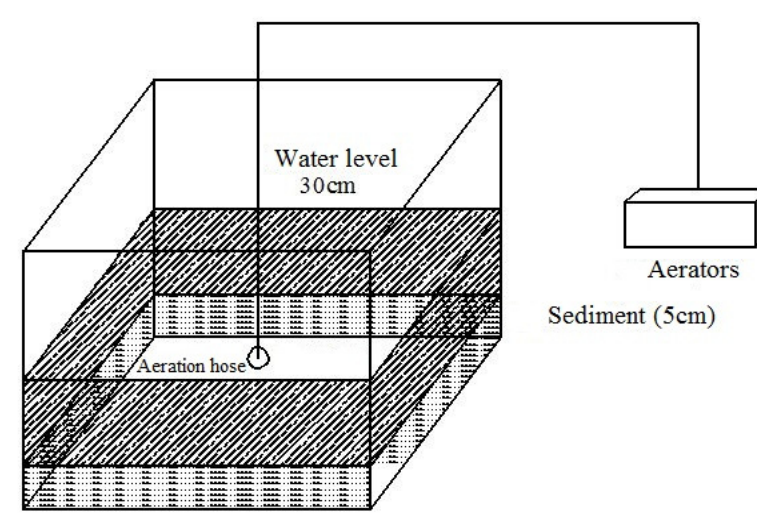

(c)

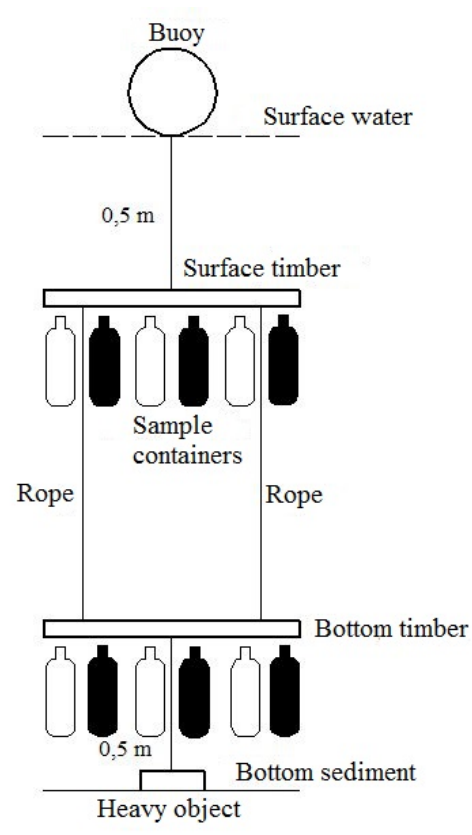

(b)

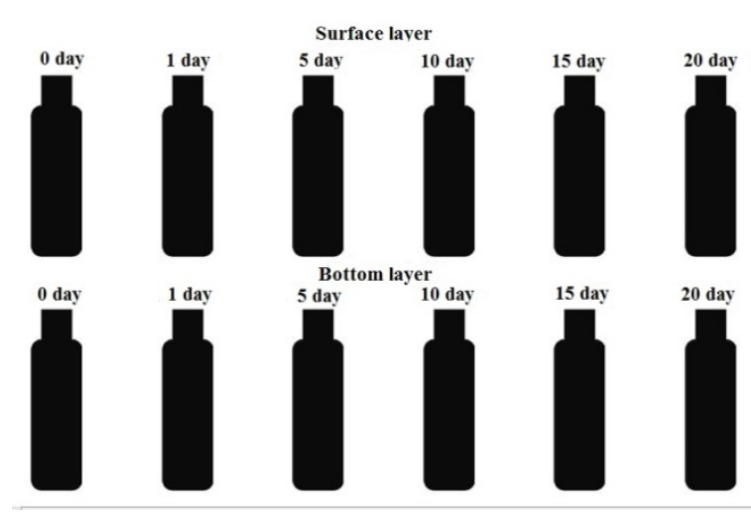

(d)

Figure 2. Experiments: (a)-Sedimentation; (b)- Photosynthesis; (c)-Dispersion; (d)-Decomposition

\section{Results and Discussion}

\subsection{Experiment Results and Calculation}

Table 1 presents calculated data of sediment rate and the dispersion pollutants from sediment to water of Thi Nai lagoon after finishing experiments. 
Table 1. Sedimentation Rate and the Dispersion Pollutants from Sediment to Water of Thi Nai Lagoon $\left(\mathrm{g} / \mathrm{m}^{2} /\right.$ day $)$

\begin{tabular}{lcccc}
\hline \multirow{2}{*}{ Parameters } & \multicolumn{2}{c}{ Sedimentation rate } & \multicolumn{2}{c}{ Dispersion rate } \\
\cline { 2 - 5 } & Rainy season & Dry season & Rainy season & Dry season \\
\hline $\mathrm{TSS}$ & 59.44 & 39.53 & 5.05 & 4.82 \\
$\mathrm{BOD}_{5}$ & 1.52 & 0.95 & 0.30 & 0.31 \\
$\mathrm{COD}$ & 8.33 & 5.65 & 1.09 & 0.97 \\
$\mathrm{~N}-\mathrm{NO}_{2}{ }^{-}$ & 0.005 & 0.005 & 0.00 & 0.00 \\
$\mathrm{~N}-\mathrm{NO}_{3}^{-}$ & 0.04 & 0.04 & 0.02 & 0.01 \\
$\mathrm{~N}-\mathrm{NH}_{4}{ }^{+}$ & 0.09 & 0.09 & 0.03 & 0.03 \\
$\mathrm{P}-\mathrm{PO}_{4}{ }^{-}$ & 0.010 & 0.011 & 0.00 & 0.00 \\
P.T & 0.55 & 0.53 & 0.19 & 0.17 \\
N.T & 3.77 & 3.42 & 0.57 & 0.50 \\
\hline
\end{tabular}

In the rainy season, sedimentation rate is higher than that in dry season 2.1 times for TSS; 1.9 times for organic matters and 1.2 times for nutrients. High sedimentation rates can reduce the contact time between organic matter and dissolved oxygen in the water column, and therefore can contribute to higher concentrations of carbon and nutrients in sediment (Pierson, Bishop, Van Sendon, Horton, \& Adamantidis, 2002). Experiment data show that sedimentation rate of pollutants is higher in site TN-LT2 due to this site is quite calm compare to site TN-LT1. The dispersion of materials from sediment to water column is also higher in rainy season, but the difference between two seasons is not much. As calculation, the area of lagoon is 38 million square meter, water volume in dry season is 86.91 million cubic meter and in rainy season is 88.81 million cubic meter (Vinh, 2014). Based on that, amount of materials settled in the bottom and amount of materials dispersed from sediment into water column in Thi Nai lagoon was calculated (Table 2).

Table 2. Amount of Materials Settled in the Bottom and Amount of Materials Dispersed from Sediment into Water Column in Thi Nai Lagoon (ton/day)

\begin{tabular}{lcccc}
\hline Parameter & \multicolumn{2}{c}{ Deposition } & \multicolumn{2}{c}{ Dispersion } \\
\cline { 2 - 5 } & Rainy season & Dry season & Rainy season & Dry season \\
\hline TSS & 3282.69 & 1504.33 & 192.25 & 183.56 \\
$\mathrm{BOD}_{5}$ & 69.13 & 36.20 & 11.38 & 11.64 \\
$\mathrm{COD}$ & 410.24 & 214.94 & 41.47 & 37.02 \\
$\mathrm{~N}-\mathrm{NO}_{2}{ }^{-}$ & 0.18 & 0.19 & 0.09 & 0.08 \\
$\mathrm{~N}-\mathrm{NO}_{3}{ }^{-}$ & 1.56 & 1.47 & 0.60 & 0.55 \\
$\mathrm{~N}-\mathrm{NH}_{4}{ }^{+}$ & 3.58 & 3.34 & 1.11 & 1.03 \\
$\mathrm{P}-\mathrm{PO}_{4}{ }^{3-}$ & 0.41 & 0.41 & 0.15 & 0.13 \\
P.T & 22.36 & 20.08 & 7.28 & 6.65 \\
N.T & 159.61 & 130.17 & 21.78 & 19.20 \\
\hline
\end{tabular}

Table 3 presents photosynthesis experiment results, in which the fresh Carbon produced by photosynthesis have plus sign (+), the amount of mineral nutrients participate in photosynthesis and consumed, have minus sign (-). From that, the amount of fresh Carbon produced and mineral nutrients consumed by photosynthesis in Thi Nai lagoon were calculated (Table 4). 
Table 3. Amount of Fresh Carbon Produced and Mineral Nutrients Consumed by Photosynthesis in Experiment Time

\begin{tabular}{|c|c|c|c|c|c|c|c|}
\hline \multicolumn{2}{|l|}{ Parameters } & \multicolumn{3}{|c|}{ Rainy season } & \multicolumn{3}{|c|}{ Dry season } \\
\hline & & Surface & Bottom & Aver. & Surface & Bottom & Aver. \\
\hline Fresh Carbon produced (mgC/l/day) & & 0.023 & 0.038 & 0.030 & 0.096 & 0.038 & 0.067 \\
\hline \multirow{4}{*}{ Mineral nutrients consumed ( $\mathrm{g} / \mathrm{l} / \mathrm{day})$} & $\mathrm{N}-\mathrm{NO}_{2}^{-}$ & -0.79 & -0.54 & -0.66 & -0.97 & -0.60 & -0.79 \\
\hline & $\mathrm{N}-\mathrm{NO}_{3}^{-}$ & -14.51 & -7.00 & -10.75 & -15.50 & -5.84 & -10.67 \\
\hline & $\mathrm{N}-\mathrm{NH}_{4}{ }^{+}$ & -6.30 & -7.00 & -6.65 & -4.72 & -4.99 & -4.85 \\
\hline & $\mathrm{P}-\mathrm{PO}_{4}{ }^{3-}$ & -2.62 & -1.24 & -1.93 & -2.04 & -1.22 & -1.63 \\
\hline
\end{tabular}

Table 4. Amount of Fresh Carbon Produced and Mineral Nutrients Consumed by Photosynthesis in Thi Nai Lagoon (ton/day)

\begin{tabular}{llcc}
\hline \multicolumn{1}{c}{ Parameters } & & Rainy season & Dry season \\
\hline Fresh Carbon produced & & 2.68 & 5.80 \\
\hline \multirow{4}{*}{ Mineral nutrients consumed } & $\mathrm{N}^{-\mathrm{NO}_{2}}{ }^{-}$ & 0.06 & 0.07 \\
& $\mathrm{~N}^{-} \mathrm{NO}_{3}{ }^{-}$ & 0.95 & 0.93 \\
& $\mathrm{~N}^{-} \mathrm{NH}_{4}{ }^{+}$ & 0.59 & 0.42 \\
& $\mathrm{P}^{-\mathrm{PO}_{4}}{ }^{3-}$ & 0,17 & 0,14 \\
\hline
\end{tabular}

In dry season (May, 2014), primary productivity of phytoplankton is higher than that in rainy season due to the radiation is very high in dry season, reach to maximum value and it speeds up photosynthesis of phytoplankton. Other side, in rainy season, due to dull weather, cloudy and less sunny that limiting photosynthesis of phytoplankton.

Decomposed experiment indicates decomposition of organic substance by micro-organisms in lagoon. During decomposed process, mineral nutrients of phosphorous and nitrogen were generated. Table 5 shows the decomposed coefficient of organic substance of water in Thi Nai lagoon and generated rate of mineral nutrients of phosphorous and nitrogen based on experiment data.

Table 5. Decomposed Coefficient of Organic Substance and the Amount of Organic Substance Decomposed in Water Column of Thi Nai Lagoon

\begin{tabular}{ccccc}
\hline Parameters & \multicolumn{2}{c}{ Decomposed coefficient $\left(\right.$ day $\left.^{-1}\right)$} & Amount of organic substance decomposed (ton/day) \\
\cline { 2 - 5 } & Rainy season & Dry season & Rainy season & Dry season \\
\hline $\mathrm{BOD}_{5}$ & -0.0649 & -0.0461 & -19.17 & -7.32 \\
$\mathrm{COD}$ & -0.0452 & -0.0442 & -38.71 & -23.84 \\
$\mathrm{~N}-\mathrm{NO}_{2}{ }^{-}$ & 0.03155 & 0.0475 & 0.105 & 0.096 \\
$\mathrm{~N}-\mathrm{NO}_{3}{ }^{-}$ & 0.0137 & 0.0170 & 0.582 & 0.518 \\
$\mathrm{~N}-\mathrm{NH}_{4}^{+}$ & 0.02985 & 0.0554 & 0.554 & 0.528 \\
$\mathrm{P}_{-} \mathrm{PO}_{4}{ }^{3-}$ & 0.04855 & 0.0589 & 0.260 & 0.218 \\
\hline
\end{tabular}

Materials exchange in Thi Nai lagoon is done through the mouth of lagoon that connects to Quy Nhon Bay. Besides, the lagoon is also received a much amount of materials from Kon and Ha Thanh Rivers. Table 6 presents materials exchanged in Thi Nai lagoon based on current and water quality monitoring data at experiment sites. 
Table 6. Materials Exchanged in Thi Nai Lagoon (ton/day)

\begin{tabular}{lcccccc}
\hline & \multicolumn{2}{c}{ End of lagoon } & \multicolumn{2}{c}{ Middle of lagoon } & \multicolumn{2}{c}{ Whole lagoon } \\
\cline { 2 - 7 } Parameters/site & Rainy season & Dry season & Rainy season & Dry season & Rainy season & Dry season \\
\hline BOD $_{5}$ & 105.00 & 69.76 & 0.01 & 15.37 & 141.45 & -79.32 \\
$\mathrm{COD}$ & 453.93 & 263.31 & 0.02 & 47.51 & 585.01 & -188.03 \\
$\mathrm{~N}^{-N O}{ }_{2}^{-}$ & 1.86 & 1.03 & 0.10 & 0.18 & 2.28 & -0.90 \\
$\mathrm{~N}^{-} \mathrm{NO}_{3}{ }^{-}$ & 23.83 & 12.94 & 1.01 & 2.56 & 28.68 & -10.74 \\
$\mathrm{~N}^{-} \mathrm{NH}_{4}{ }^{+}$ & 9.98 & 5.61 & 0.50 & 0.98 & 12.30 & -4.44 \\
$\mathrm{P}_{\mathrm{PO}}{ }^{3-}$ & 3.31 & 1.72 & 0.13 & 0.36 & 3.90 & -1.34 \\
$\mathrm{P}-\mathrm{T}$ & 40.15 & 21.53 & 0.00 & 4.61 & 48.14 & -21.31 \\
$\mathrm{~N}-\mathrm{T}$ & 556.19 & 315.59 & 0.03 & 66.99 & 691.69 & -307.13 \\
$\mathrm{TSS}$ & 2641.66 & 1763.68 & 0.10 & 324.31 & 3612.87 & -1407.30 \\
Chlorophyll a & 0.52 & 0.33 & 0.03 & 0.06 & 0.68 & -0.31 \\
\hline
\end{tabular}

Note: plus sign (-): flow from the sea to lagoon; minus sign (+): flow from lagoon to the sea.

Thus, in rainy season, a big amount of water from rivers discharged into lagoon increasing water exchange of the lagoon. On the contrary, in dry season, the water mass from the Quy Nhon Bay come into lagoon dominated, increasing accumulation of pollutants in lagoon.

\subsection{Mass Balance in Thi Nai Lagoon}

Mass balance of a water body in a day only used for $\mathrm{BOD}_{5}, \mathrm{COD}$ (represented for organic pollutants) and mineral nutrients (nitrate, nitrite, ammonium and phosphate) that participate in self-purification and can be calculated from sedimentation, photosynthesis, decomposition, dispersion and material exchange processes. Table 7 and 8 present the mass balance in Thi Nai lagoon in both dry and rainy seasons.

Table 7. Mass Balance of Pollutants in Thi Nai Lagoon (Rainy season)

Unit: ton/day

\begin{tabular}{lccccccc}
\hline Parameter & $\begin{array}{c}\text { Pollution } \\
\text { load }(*)\end{array}$ & Photosynthesis & Dispersion & Sedimentation & Decomposition & $\begin{array}{c}\text { Material } \\
\text { Exchange }\end{array}$ & Balance \\
\hline $\mathrm{BOD}_{5}$ & 10.45 & 2.68 & 11.38 & -69.13 & -19.17 & -141.45 & -205.24 \\
$\mathrm{COD}$ & 48.79 & 4.12 & 41.47 & -410.24 & -38.71 & -585.01 & -939.58 \\
$\mathrm{~N}-\mathrm{NO}_{2}{ }^{-}$ & 0.010 & -0.06 & 0.09 & -0.18 & 0.10 & -2.28 & -2.32 \\
$\mathrm{~N}-\mathrm{NO}_{3}{ }^{-}$ & 0.091 & -0.95 & 0.60 & -1.56 & 0.58 & -28.68 & -29.93 \\
$\mathrm{~N}-\mathrm{NH}_{4}{ }^{+}$ & 3.09 & -0.63 & 1.11 & -3.58 & 0.55 & -12.30 & -11.75 \\
$\mathrm{P}-\mathrm{PO}_{4}{ }^{3-}$ & 1.41 & -0.17 & 0.15 & -0.41 & 0.26 & -3.90 & -2.65 \\
\hline
\end{tabular}

Note: plus sign (+) : amount of pollutants that produced or added in the lagoon; minus sign (-): amount of pollutants that decomposed or lost in lagoon; (*) After Hoa, 2014; Vinh \& Thuy, 2011.

Table 7 indicates that, the self-purification of lagoon is quite good in rainy season. The materials exchange process play an important role in purification of lagoon in rainy season. In dry season, the self-purification is less due to decreasing of material exchange, leading accumulation of organic substance, ammonium and phosphate (Table 8). 
Table 8. Mass Balance of Pollutants in Thi Nai Lagoon (Dry season)

Unit: ton/day

\begin{tabular}{lccccccc}
\hline Parameter & $\begin{array}{c}\text { Pollution } \\
\text { load }(*)\end{array}$ & Photosynthesis & Dispersion & Sedimentation & Decomposition & $\begin{array}{c}\text { Material } \\
\text { Exchange }\end{array}$ & Balance \\
\hline BOD5 & 10.45 & 5.80 & 11.64 & -36.20 & -7.32 & 79.32 & 63.68 \\
$\mathrm{COD}$ & 48.79 & 8.94 & 37.02 & -214.94 & -23.84 & 188.03 & 43.99 \\
$\mathrm{~N}-\mathrm{NO}_{2}{ }^{-}$ & 0.010 & -0.05 & 0.08 & -0.19 & 0.10 & 0.90 & 0.83 \\
$\mathrm{~N}-\mathrm{NO}_{3}^{-}$ & 0.091 & -0.87 & 0.55 & -1.47 & 0.52 & 10.74 & 9.51 \\
$\mathrm{~N}-\mathrm{NH}_{4}{ }^{+}$ & 3.09 & -0.49 & 1.03 & -3.34 & 0.53 & 4.44 & 5.34 \\
$\mathrm{P}-\mathrm{PO}_{4}{ }^{3-}$ & 1.41 & -0.15 & 0.13 & -0.41 & 0.22 & 1.34 & 2.55 \\
\hline
\end{tabular}

Note: plus sign (+) : amount of pollutants that produced or added in the lagoon; minus sign (-): amount of pollutants that decomposed or lost lagoon; (*) After Hoa, 2014; Vinh \& Thuy, 2011.

In the above processes, the pollution load discharged into the lagoon is result from human activities, and it needs to be controlled. If this discharge is restrict controlled, the amount of pollution load would be decreased and the self-purification of lagoon would be enhanced. The remaining processes are natural processes; in which material exchange is dominate to self-purification of the lagoon. However, if consider to true self - purification which are photosynthesis and decomposition, it is found that there is the accumulation of nitrite, ammonium and phosphate in water.

The experiment results show that, in rainy season, the decomposition capacity of substances in water is quite good, primary productivity of water body is low, sedimentation is high and good water exchange; therefore the mass balance have minus sign (-). It indicates that the natural self-purification of lagoon is good. On contrary, in dry season, thought primary productivity of water body is higher, but other processes such as sedimentation, decomposition and water exchange are less so there is the accumulation of pollutants in water, the mass balance have plus sign (+). While, Thi Nai lagoon is located in the South Central Coast region of Viet Nam where featured with typical tropical monsoon climate with the average temperature of $27^{\circ} \mathrm{C}$. Rainy season normally lasts from September to December and dry season lasts from January to August or September. Thus, the accumulation of pollutants in the Thi Nai lagoon can be happen and predicted.

This finding is initial research and need to have more studies on self-purification of Thi Nai lagoon in different times in year to confirm it.

\section{Conclusions}

Experiments were carried out in Thi Nai lagoon to assess its self-purification. It is found that the self-purification of Thi Nai lagoon is quite good in rainy season, and the domination process is material exchange. In dry season, due to the less of material exchange, there is accumulation of pollutants in lagoon. Calculation results help us understanding partly nature of self- purification in Thi Nai lagoon and the main process dominate its purification. However, this study only done in 3 days for each season, and in another hand, pollution load discharged into lagoon is used similar for everyday; therefore, the mass balance calculation meets some certain limits. We need some further studies on self-purification of Thi Nai lagoon in different times in year to clarify its purification.

The mass balance study results show that the controlling of wastewater into lagoon is very important in order to minimum the accumulation of pollutants in lagoon. When the pollution load increases, the border between accumulation and not-accumulation is very tiny due to coefficients of self-purification processes changed in negative trend. Thus, treatment of wastewater before discharged into Thi Nai lagoon is necessary.

\section{Acknowledgement}

Studies in this paper were done based on National Project "Assessment of environmental carrying capacity of some typical coastal water bodies of Viet Nam in order to maintain the sustainable development", coded KC09.17/11-15. Authors would like to thanks the project coordinator for publish this paper. 


\section{References}

Beyers, R., \& Odum, H. T. (1993). Ecological Microcosms. New York: Springer Verlag.

Drinan, J. E., \& Spellman, F. R. (2001). Stream Ecology and Self-Purification: An Introduction (2nd ed.). A Technomic Publishing Co. Inc.

Fujie, K., \& Hu, H. Y. (2002). Water quality standards-Vol II-Minimizing loads on water bodies (EOLSS-UNESCO).

Grice, G., \& Reeve, M. (eds.). (1982). Marine Mesocosms: Biological and Chemical Research in Experimental Ecosystem. New York: Springer Verlag.

Hanelore, M. (2013). The Process pf Self-Purification in the Rivers. International Multidisciplinary Scientific GeoConference: SGEM: Surveying Geology \& mining Ecology Management (pp. 409-416).

Hily, C. (1991). Is the activity of benthic suspension feeders a factor controlling water quality in the Bay of Brest?. Marine Ecology Progress Series. Oldendorf, 69(1), 179-188.

Hoa, N. T. P. (2014). Study and assess pollution load from landbase into Thi Nai lagoon, in project "Assessment of environmental carrying capacity of some typical coastal water bodies of Viet Nam in order to maintain the sustainable development. coded KC09.17/11-15 - on-going project (in Vietnamese)

Ifabiyi, I. P. (2008). Self purification of a freshwater stream in Ile-Ife: lessons for water management. J. Hum. Ecol, 24(2), 131-137.

JICA. (1999). Study for environmental management of Ha Long Bay. Final report, Volume II, III (in both Vietnamese and English)

Li, K., Su, Y., Ying, J., Wang, X., \& Mu, J. (2013). Environmental capacity of petroleum hydrocarbon pollutants in Jiaozhou Bay, China: Modeling and calculation. Journal of Ocean University of China, 12(1), 70-76.

Logan, B. E., \& Hunt, J. R. (1987). Advantages to microbes of growth in permeable aggregates in marine systems1. Limnology and Oceanography, 32(5), 1034-1048.

Loo, L. O., \& Rosenberg, R. (1989). Bivalve suspension-feeding dynamics and benthic-pelagic coupling in an eutrophicated marine bay. Journal of Experimental Marine Biology and Ecology, 130(3), 253-276.

Mandi, L., Houhoum, B., Asmama, S., \& Schwartzbrod, J. (1996). Wastewater treatment by reed beds: an experimental approach. Water Research, 30(9), 2009-2016.

Pierson, W. L., Bishop, K., Van Sendon, D., Horton, P. R., \& Adamantidis, C. A. (2002). Environmental Water Requirements to Maintain Estuarine Processes. Environmental Flows Initiative Technical Report, Report Number 3, Commonwealth of Australia.

Stimson, J., Larned, S., \& McDermid, K. (1996). Seasonal growth of nutrient availability, temperature and herbivory on growth rate. J. Exp. Mar. Biol. Ecol., 196, 53-77.

UNESCO. (1982). Dispersion and self-purification of pollutants in surface water systems. A contribution to the International Hydrological program.

Vinh, V. D (2014). Characteristic of hydro-dynamic and water exchange of Thi Nai lagoon, in project "Assessment of environmental carrying capacity of some typical coastal water bodies of Viet Nam in order to maintain the sustainable development". coded KC09.17/11-15 - on-going project. (in Vietnamese).

Vinh. L.T, \& Thuy, N. T. T. (2011). Influence of waste sources to water quality in Thi Nai lagoon. Joural of Marine Science and Technology T11, 4, 35-46. (in Vietnmese).

\section{Copyrights}

Copyright for this article is retained by the author(s), with first publication rights granted to the journal.

This is an open-access article distributed under the terms and conditions of the Creative Commons Attribution license (http://creativecommons.org/licenses/by/3.0/). 